\title{
The Ecology of Antihypertensives in the United States, 1997-2017
}

\author{
Michael E. Johansen, MD, MS ${ }^{1,2}$, Joshua D. Niforatos, MD, MTS ${ }^{3} \odot$, and \\ Jeremey B. Sussman, $M D, M S^{4}$
}

'Grant Family Medicine, Ohio Health, Columbus, OH, USA; ${ }^{2}$ Heritage College of Osteopathic Medicine, Ohio University, Dublin, OH, USA; ${ }^{3}$ Department of Emergency Medicine, The Johns Hopkins University School of Medicine, Baltimore, MD, USA; ${ }^{4}$ Department of Internal Medicine, Division of General Medicine, University of Michigan, Ann Arbor, MI, USA.

OBJECTIVE: Antihypertensives are the most used medication type in the USA, yet there remains uncertainty about the use of different antihypertensives. We sought to characterize use of antihypertensives by and within medication class(es) between 1997 and 2017.

PATIENTS AND METHODS: A repeated cross-sectional study of 493,596 adult individuals using the 1997-2017 Medical Expenditure Panel Survey (MEPS). The Orange Book was used for adjunctive information. The primary outcome was the estimated use by and within antihypertensive medication class(es).

RESULTS: The proportion of individuals taking any antihypertensive during a year increased from 1997 to the early 2010s and then remained stable. The proportion of adults using angiotensin II receptor blockers (ARBs) and dihydropyridine calcium channel blockers (CCBs) increased during the study period, while angiotensinconverting enzyme inhibitors (ACE-Is) increased until 2010 after which rates remained stable. Beta-blocker use was similar to that of ACE-Is with an earlier decline starting in 2012. Thiazide diuretic use increased from 1997 to 2007, leveled off until 2014, and declined from 2015 to 2017. Non-dihydropyridine CCB use declined throughout the study. ACE-Is, ARBs, CCBs, thiazide diuretics, and loop diuretics all had one dominant in-class medication. There was a clear increase in the use of losartan within ARBs, lisinopril within ACE-Is, and amlodipine within CCBs following generic conversion. Furosemide and hydrochlorothiazide started with and maintained a dominant position in their classes. Metoprolol use increased throughout the study and became the dominant beta-blocker.

CONCLUSIONS: Antihypertensive classes appear to have a propensity to equilibrate to an individual medication, despite a lack of outcomes-based research to compare medications within a class.

\section{Abbreviations}

$\begin{array}{ll}\text { MEPS } & \text { Medical expenditure panel survey } \\ \text { ACE-I } & \text { Angiotensin-converting enzyme inhibitor } \\ \text { ARB } & \text { Angiotensin receptor blocker } \\ \text { CCB } & \text { Dihydropyridine calcium channel }\end{array}$

Received May 2, 2020

Accepted September 3, 2020

Published online September 23, 2020
$\mathrm{J}$ Gen Intern Med 36(3):699-704

DOI: $10.1007 / \mathrm{s} 11606-020-06214-1$

(c) Society of General Internal Medicine 2020

\section{INTRODUCTION}

Hypertension costs the USA an estimated \$131 billion yearly, ${ }^{1}$ and is the primary or contributing cause of over half a million US deaths each year. ${ }^{2}$ Over one-fifth of adults in the USA take an antihypertensive medication, which makes them the most used type of medications in the USA. ${ }^{3,4}$ Antihypertensives are also among the best-studied of all drugs, with at least 464,000 people randomized into antihypertensive clinical trials by 2003. ${ }^{5}$ They are also the topic of multiple high-profile clinical practice guidelines and performance measures. ${ }^{6,7}$ Which antihypertensive drugs are used, why they are used, and ensuring that effective clinical research exists to use the most effective drugs possible could have a large public health impact. But which drugs are used and for what reason is not always known.

A recent study assessing trends overtime in blood pressure management in the outpatient setting saw increases in multidrug therapy for hypertension with angiotensin-converting enzyme inhibitors, calcium channel blockers, and betablockers as the most frequently prescribed class of blood pressure medications in $2016 . .^{8}$ Nevertheless, there remain relatively few studies of the determinants of the use of specific classes of antihypertensive medications and even fewer examining which drugs are used within specific classes. ${ }^{3,}{ }^{9-12}$ Few trials have directly compared drugs within classes. As a result, guidelines and previous studies have mostly referred to medications as classes rather than unique individual compounds. However, indirect comparisons have provided evidence that there could be important intra-class differences. ${ }^{13-16}$ Therefore, understanding the trends of between-class and within-class clinical use of antihypertensives could help guide both implementation and research going forward.

Given this context, the primary goal of this study is to gain a better understanding of the between- and within-class trends in antihypertensive medication use over the last 20 years. Due to 
the complexity of individual decision-making, this descriptive study compiles a hypothesis generated list of observations based on an understanding of the literature. We hypothesized that between-class trends occur in relation to cost of medications, whereas within-class trends of antihypertensive agents occur in relation to availability and generic conversion.

\section{METHODS}

\section{Study Participants}

A repeated cross-sectional study of the Medical Expenditure Panel Survey (MEPS) was used to describe trends in antihypertensive medication use over time ${ }^{17}$ MEPS is sponsored by the Agency of Healthcare Research and Quality (AHRQ) and is representative of the non-institutionalized population of the USA. Each year of the survey is comprised of two overlapping cohorts, which are interviewed five times over the 2 years. The survey includes information regarding demographic, socioeconomic, and prescription medication utilization. All adult individuals included in the survey between 1997 and 2017 were included in the analysis.

\section{Study Variables}

Antihypertensive medications were identified through a combination of therapeutic classification and prescription medication name. The survey uses numerous methods to achieve accurate reporting of prescription medications including contacting pharmacies. ${ }^{18-20}$ Previous studies have validated the accuracy of chronic medication reporting in MEPS. ${ }^{21}$ Included classes in the study were angiotensin-converting enzyme inhibitor (ACE-I), thiazide diuretic, angiotensin receptor blocker (ARB), beta-blocker, loop diuretic, dihydropyridine calcium channel blockers (CCB), nondihydropyridine $\mathrm{CCB}$, aldosterone receptor antagonists, hydralazine, and clonidine. Other drug classes were not studied given low levels of use and/or numerous therapeutic uses across numerous categories. Within these classes, individual medications were identified by name. Combination medications were reported in applicable categories. An individual was identified as a medication user if he or she had any use of the medication during a given year. Generic availability of medications was identified as the first approved Abbreviated New Drug Application (ANDA) through the Food and Drug Administration (FDA).

\section{Analysis}

Complex survey weights were used in all analyses to make these analyses representative of the non-institutionalized population of the USA. The figures report $95 \%$ confidence intervals.

The OhioHealth Institutional Review Board ruled the study exempt. All analyses used STATA15 (College Station, TX).

\section{RESULTS}

Between 1997 and 2017, 493,596 individuals were identified. We identified 43 relevant antihypertensive medications among 10 classes (Table 1). All but 4 of these drugs were approved before our study dataset began in 1997, but 26 achieved generic status between 1997 and 2016. The newest drugs were 3 angiotensin receptor blockers and nebivolol.

Table 1 Antihypertensive Medications Brand and Generic Approval Dates

\begin{tabular}{|c|c|c|}
\hline Antihypertensive & Approval & $\overline{\text { Generic }}$ \\
\hline \multicolumn{3}{|l|}{ ACE inhibitors } \\
\hline Lisinopril & 1987 & 2002 \\
\hline Enalapril & 1985 & 2000 \\
\hline Ramipril & 1991 & 2005 \\
\hline Benazepril & 1991 & 2004 \\
\hline Captopril & 1981 & 1995 \\
\hline Perindopril & 1993 & 2009 \\
\hline Quinapril & 1991 & 2004 \\
\hline Fosinopril & 1991 & 2003 \\
\hline Moexipril & 1995 & 2003 \\
\hline Trandolapril & 1996 & 2006 \\
\hline \multicolumn{3}{|c|}{ Thiazide and thiazide-like diuretics } \\
\hline Hydrochlorothiazide* & 1959 & \\
\hline Chlorthalidone & 1960 & 1981 \\
\hline \multicolumn{3}{|c|}{ DHP calcium channel blockers } \\
\hline Amlodipine & 1992 & 2005 \\
\hline Nifedipine & 1981 & $1989 * *$ \\
\hline Isradipine & 1990 & 2006 \\
\hline Felodipine & 1991 & 2004 \\
\hline Nicardipine & 1988 & 1996 \\
\hline Nisoldipine & 1995 & 2008 \\
\hline \multicolumn{3}{|c|}{ non-DHP calcium channel blockers } \\
\hline Diltiazem & 1982 & 1992 \\
\hline Verapamil & 1981 & 1986 \\
\hline \multicolumn{3}{|c|}{ Angiotensin II receptor blockers } \\
\hline Losartan & 1995 & 2010 \\
\hline Olmesartan & 2002 & 2016 \\
\hline Valsartan & 1996 & 2014 \\
\hline Irbesartan & 1996 & 2012 \\
\hline Telmisartan & 1998 & 2014 \\
\hline Candesartan & 1998 & 2013 \\
\hline Eprosartan $* * * *$ & 1997 & 2011 \\
\hline \multicolumn{3}{|l|}{ Beta-blockers } \\
\hline Metoprolol & 1978 & $1993 * * *$ \\
\hline Atenolol & 1981 & 1991 \\
\hline Carvedilol & 1995 & 2007 \\
\hline Nebivolol & 2007 & 2015 \\
\hline Propranolol & 1967 & 1985 \\
\hline Bisoprolol & 1992 & 2000 \\
\hline Labetalol & 1984 & 1998 \\
\hline Nadolol & 1979 & 1993 \\
\hline Acebutolol $* * * *$ & 1984 & 1995 \\
\hline \multicolumn{3}{|l|}{ Loop diuretics } \\
\hline Furosemide & 1966 & 1981 \\
\hline Torsemide & 1993 & 2002 \\
\hline Ethacrynic acid & 1982 & 2016 \\
\hline Bumetanide & 1983 & 1995 \\
\hline \multicolumn{3}{|c|}{ Aldosterone receptor antagonists } \\
\hline Spironolactone & 1960 & 1980 \\
\hline \multicolumn{3}{|l|}{ Alpha-2 agonist } \\
\hline Clonidine & 1974 & 1986 \\
\hline \multicolumn{3}{|l|}{ Vasodilators } \\
\hline Hydralazine & 1953 & 1974 \\
\hline \multicolumn{3}{|c|}{$\begin{array}{l}\text { Antihypertensive brand and generic approval dates from the Orange } \\
\text { Book }\end{array}$} \\
\hline \multicolumn{3}{|c|}{$\begin{array}{l}\text { Abbreviations: ACE, angiotensin-converting enzyme; DHP, } \\
\text { dihydropyridine; non-DHP, non-dihydropyridine } \\
\text { *Hydrochlorothiazide has had numerous brands approved } \\
* * \text { Extended release available in } 1989 \text { and generic in } 1999 \\
* * * \text { Extended release } 1989 \text {, generic } 2006 \\
* * * * \text { Not included in the analysis because of low levels of use }\end{array}$} \\
\hline
\end{tabular}




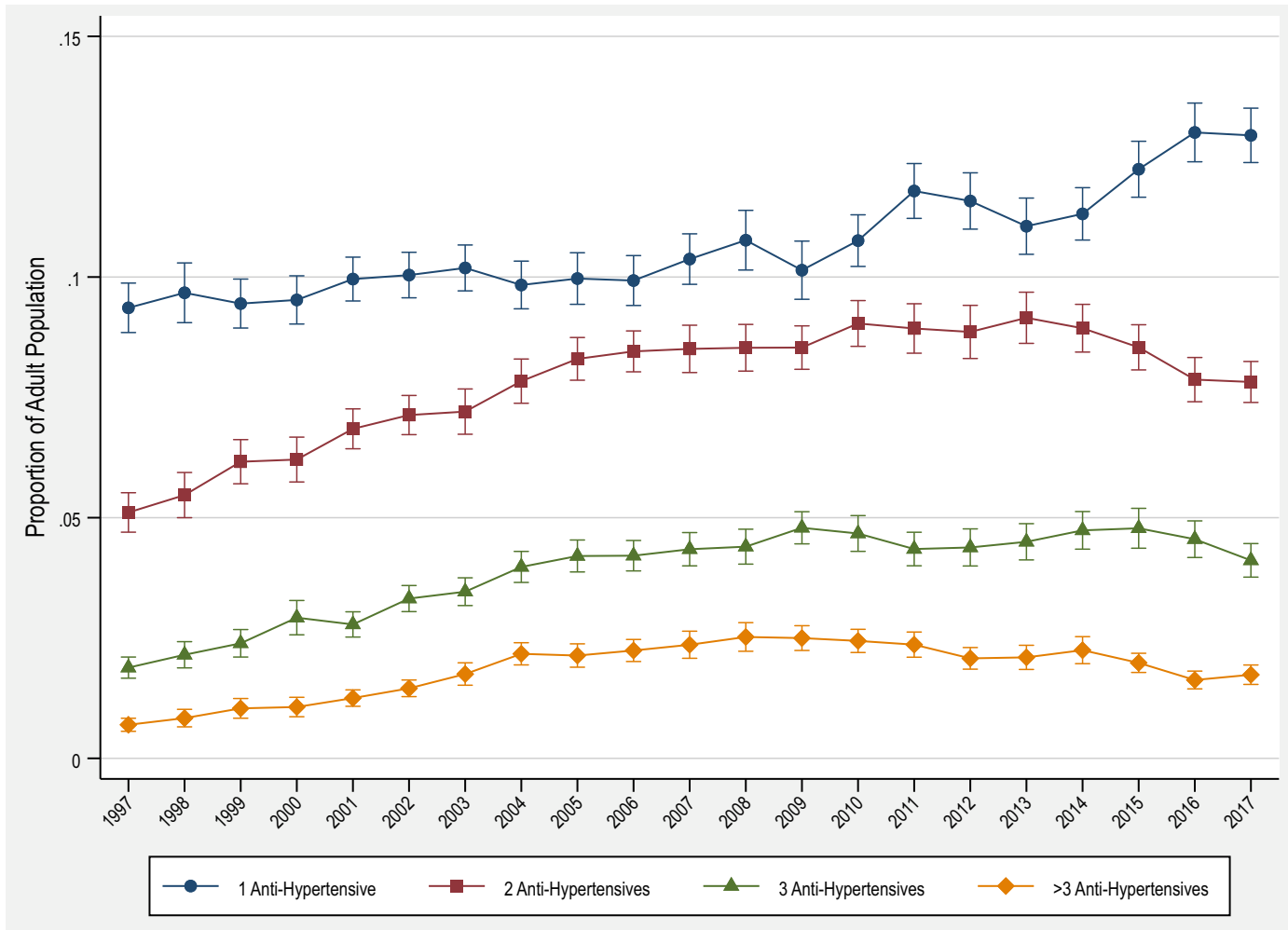

Figure 1 Proportion of the adult population on antihypertensives who are on a particular number of antihypertensive medication classes between 1997 and 2017. A user was defined by the report of any medication in a medication class. Data from the 1997 to 2017 Medical Expenditure Panel Survey were used. Brackets represent 95\% confidence intervals.

The proportion of individuals taking antihypertensive medication during a year increased from 1997 to the early $2010 \mathrm{~s}$ (Fig. 1). The proportion taking 2, 3, and 4 medications all followed a similar pattern. However, from 2015 to 2017 , the proportion of the population taking 2 or more medications declined, while the number taking one increased.

Use of drugs within classes changed substantially over time (Fig. 2). Use of ARBs and dihydropyridine CCBs increased

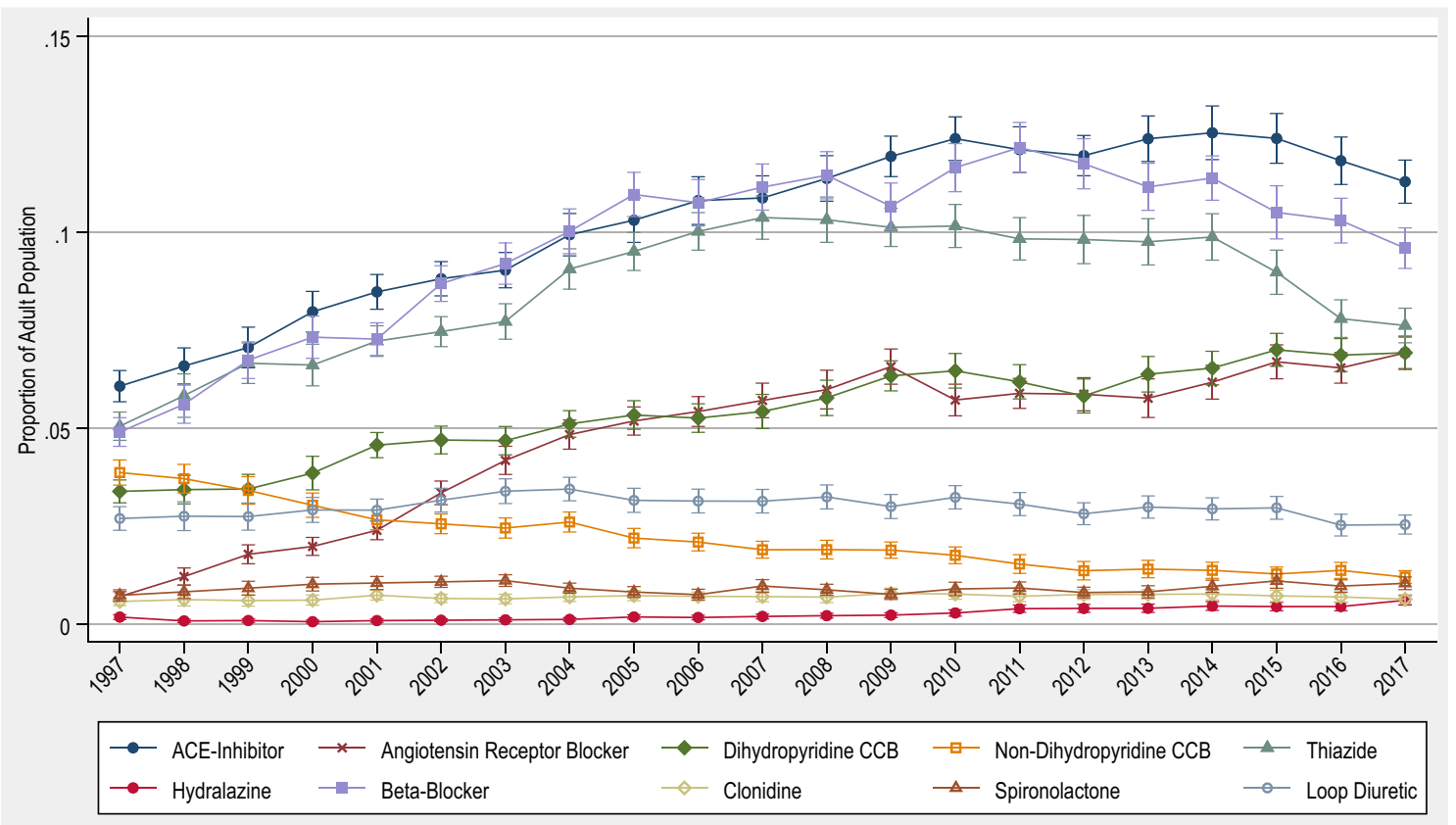

Figure 2 Proportion of Adult Population Using Antihypertensive from Medication Classes During a Year Using the 1997-2017 Medical Expenditure Panel Survey. Brackets represent 95\% confidence intervals. ACE, angiotensin-converting enzyme; CCB, calcium channel blocker. 
substantially during the study period. The proportion of the population who used ACE-Is increased until 2010 after which rates remained stable before a small decline in 2016-2017. Beta-blocker use was similar to that of ACE-Is with an earlier decline starting in 2012. Thiazide diuretic use increased from 1997 to 2007, leveled off until 2014, and declined from 2015 to 2017. Non-dihydropyridine CCB use declined throughout the study period. Loop diuretic, spironolactone, and clonidine rates of use were largely unchanged, while the proportion of people using hydralazine increased slightly.

Within classes, there was a striking tendency toward one drug developing one dominance in the class, but when the drug became dominant varied greatly (Fig. 3 ). The thiazide diuretic hydrochlorothiazide and the loop diuretic furosemide were dominant before 1997 began and became more so by 2017. The ACE-I lisinopril, ARB losartan, beta-blocker metoprolol, and CCB amlodipine all became dominant. Withinclass dominance sometimes followed generic conversion, but sometimes predated it. The dominant drug was the first introduced in 3 of 6 major classes.

\section{DISCUSSION}

Our findings show a mismatch between within-class and between-class use choices of antihypertensive medications.
Within classes, we found that most antihypertensive medication classes eventually equilibrate to one dominant medication. There was no clear evidence that the medication that became dominant did so for reasons of formal studies demonstrating superiority within the class. The dominant medication was not consistently associated with early entry or early generic availability. Drugs with some evidence of comparative advantage (i.e., chlorthalidone, torsemide) ${ }^{22-26}$ did not gain dramatical change in use, while atenolol did appear to decrease in use with less robust evidence. ${ }^{27-29}$

However, between-class medication use may be partly associated with key studies like SPRINT, and clinical practice guidelines. ${ }^{30}$ As guidelines until 2014 recommended generally intensifying treatment, overall use followed. With the decline in treatment intensity recommended in the 2014 clinical practice guidelines, ${ }^{31}$ there was a small change in clinical practice. Treatments did not appear to change dramatically after either ALLHAT or SPRINT trials. ${ }^{32}$ Medications with more negative harm profiles had declining use over time. ${ }^{33-35}$ Beta-blockers and CCBs had more movement over the course of the study, which might have been related to mechanistic differences and alternative uses of individual medications.

These data do raise the concern that if small-to-moderate differences in effect or adverse events within classes exist (i.e., phenformin in biguanides or troglitazone in thiazolidinediones), current practice may not recognize those

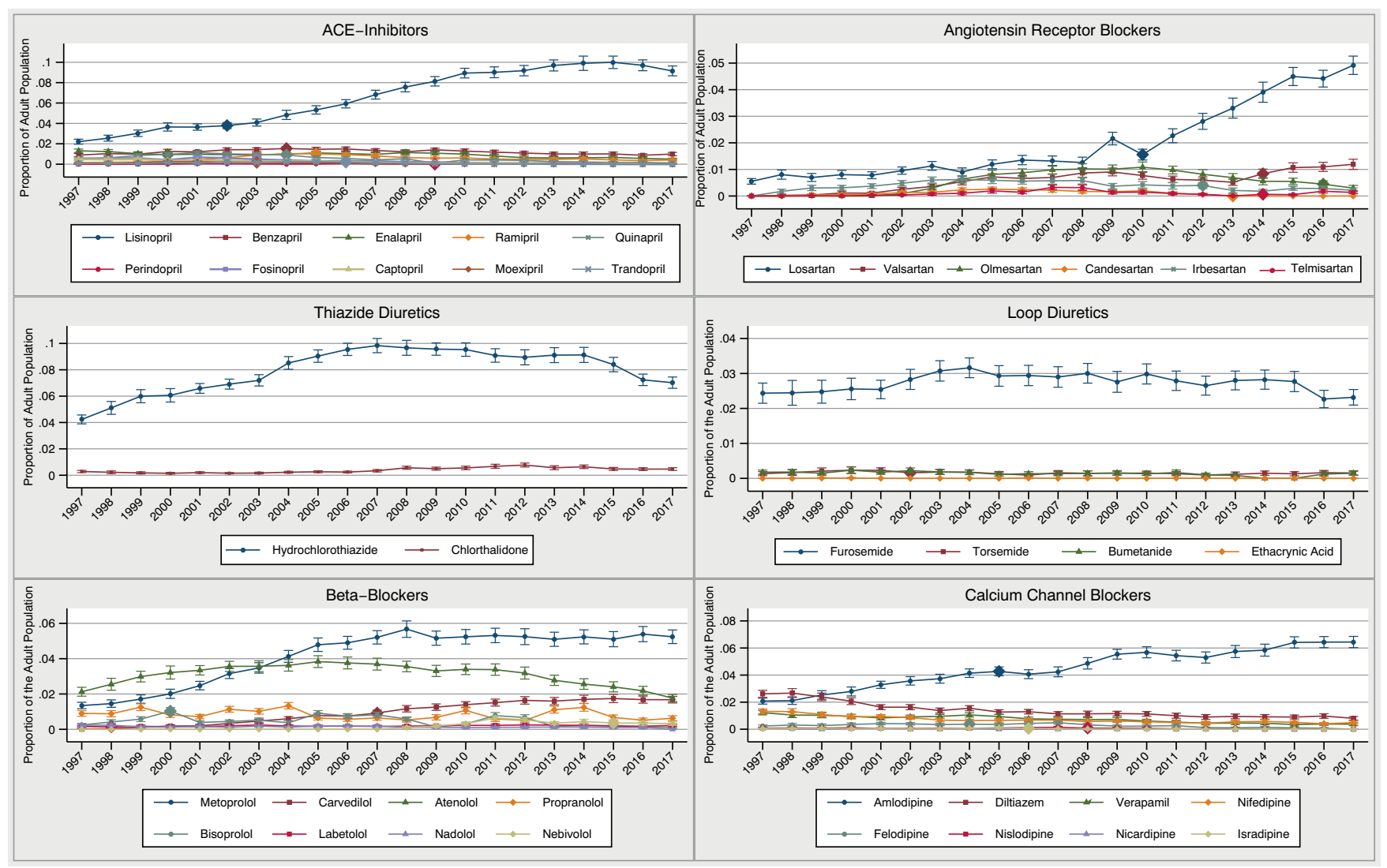

Figure 3 Information on the Proportion of Adult Population using Different Medications by Medication Class by Year. The 1997-2017 Medical Expenditure Panel Survey was used. The Y-axis represents the proportion of the adult population. Large diamonds represent the year a medication had an approved generic (also see Table 1). Brackets represent 95\% confidence intervals. ACE, angiotensin-converting enzyme. 
differences. For instance, if one of the numerous ACE-Is lowered overall mortality or disease-oriented outcomes by $10 \%$ more than other drugs of that class, it could improve the health or adherence to medications of a population, though would require very large clinical trials to be effective, likely four times the size of the SPRINT trial, assuming otherwise similar populations. Determining when medications and medication classes will justify these studies would be challenging and require foresight. Although a few comparative trials are underway (e.g., ClinicalTrials.gov NCT03978884, NCT03928145, NCT02185417), these obstacles are formidable. Alternatives to classical clinical trials offer some hope, but challenges remain with implementing these types of trials. ${ }^{36}$

Although it is beyond the scope of this study to determine causal drivers of the trends observed in this paper, there are a few potential hypotheses as it relates to between-class prescribing. Previous studies have noted geographic and specialty variation in adherence to clinical practice guidelines for hypertension, ${ }^{37,38}$ as well as differences in prescribing for younger and older patients suggesting consideration of risks/ benefits of different medications. ${ }^{39,}{ }^{40}$ Between-classes variation may also be due to tolerability of side effect profiles ${ }^{41}$ and generic availability, as well as physicians-in-training adopting practice style of senior physicians.

A few limitations of this study are worth noting. First, the high-level (ecological) observational nature of our data makes strong explanatory conclusions inappropriate. We cannot rule out residual confounding, demographic or health changes, costs, or other unmeasured causes of change in use, including advertising and promotion. ${ }^{42-45}$ Additional limitations include possible under-reporting of medications, a lack of biometric measurements, and potential utilization of certain medications for non-blood pressure-related purposes.

\section{CONCLUSION}

We found that over the last 20 years, antihypertensive drug classes have tended to equilibrate on one in-class medication. Additionally, there have been shifts in the types and amount of medications used in the population. Future research on comparative effectiveness for within-class medications early in the life cycle that are probable to have widespread use might improve health. In the absence of within-class randomized clinical trials, future funding for building the infrastructure for randomized evaluations in the ambulatory setting might be an avenue to do these trials, though these study designs are not without limitations. ${ }^{30}$ Without this renewed focus on within-class drug efficacy, prescribing patterns for antihypertensive medications within-class and between-class may continue to be done in the presence of considerable uncertainty.

Corresponding Author: Michael E. Johansen, MD, MS; Grant Family Medicine, Ohio Health, Columbus, OH, USA (e-mail: michael.johansen@ohiohealth.com).

\section{Compliance with Ethical Standards:}

Conflict of Interest: The authors declare that they have no conflict of interest.

\section{REFERENCES}

1. Kirkland EB, Heincelman M, Bishu KG, et. al. Trends in healthcare expenditures among US adults with hypertension: national estimates, 2003-2014. J Am Heart Assoc. 2018;7:e008731.

2. Centers for Disease Control and Prevention, National Center for Health Statistics. Underlying Cause of Death, 1999-2018. CDC WONDER Online Database. Atlanta, GA: Centers for Disease Control and Prevention; 2019. Accessed June 10, 2020.

3. Shah SJ, Stafford RS. Current Trends of Hypertension Treatment in the United States. Am J Hypertens. 2017;30(10):1008-1014. https://doi. org/10.1093/ajh/hpx085

4. Fuentes AV, Pineda MD, Venkata KCN. Comprehension of Top 200 Prescribed Drugs in the US as a Resource for Pharmacy Teaching, Training and Practice. Pharm Basel Switz. 2018;6(2). https://doi.org/10. 3390/pharmacy6020043

5. Law MR, Wald NJ, Rudnicka AR. Quantifying effect of statins on low density lipoprotein cholesterol, ischaemic heart disease, and stroke: systematic review and meta-analysis. BMJ. 2003;326(7404):1423. https://doi.org/10.1136/bmj.326.7404.1423

6. Whelton PK, Carey RM, Aronow WS, et al. 2017 ACC/AHA/AAPA/ $\mathrm{ABC} / \mathrm{ACPM} / \mathrm{AGS} / \mathrm{APhA} / \mathrm{ASH} / \mathrm{ASPC} / \mathrm{NMA} / \mathrm{PCNA}$ Guideline for the Prevention, Detection, Evaluation, and Management of High Blood Pressure in Adults: A Report of the American College of Cardiology/ American Heart Association Task Force on Clinical Practice Guidelines. J Am Coll Cardiol. 2018;71(19):e127-e248. https://doi.org/10. 1016/j.jacc.2017.11.006

7. Casey DE, Thomas RJ, Bhalla V, et al. 2019 AHA/ACC Clinica Performance and Quality Measures for Adults With High Blood Pressure: A Report of the American College of Cardiology/American Heart Association Task Force on Performance Measures. J Am Coll Cardiol. 2019;74(21):2661-2706. https://doi.org/10.1016/j.jacc.2019.10.001

8. Scholcoff C, Kay C, Nickoloff S, Jackson JL. Trends in Systolic Blood Pressure Control and Management in the USA, 2007 to 2016 [published online ahead of print, 2020 May 29]. J Gen Intern Med. 2020;https://doi. org/10.1007/s11606-020-05812-3.

9. Gu Q, Burt VL, Dillon CF, Yoon $\mathbf{S}$. Trends in antihypertensive medication use and blood pressure control among United States adults with hypertension: the National Health And Nutrition Examination Survey, 2001 to 2010. Circulation. 2012;126(17):2105-2114. https:// doi.org/10.1161/CIRCULATIONAHA. 112.096156

10. Jarari N, Rao N, Peela JR, et al. A review on prescribing patterns of antihypertensive drugs. Clin Hypertens. 2015;22:7. https://doi.org/10. 1186/s40885-016-0042-0

11. Fang J, Gillespie C, Ayala C, Loustalot F. Prevalence of Self-Reported Hypertension and Antihypertensive Medication Use Among Adults Aged $\geq 18$ Years - United States, 2011-2015. MMWR Morb Mortal Wkly Rep. 2018;67(7):219-224. https://doi.org/10.15585/mmwr.mm6707a4

12. Johansen ME, Yun J, Griggs JM, Jackson EA, Richardson CR. AntiHypertensive Medication Combinations in the United States. J Am Board Fam Med JABFM. 2020;33(1):143-146. https://doi.org/10.3122/jabfm. 2020.01.190134

13. Fretheim A, Odgaard-Jensen J, Brørs O, et al. Comparative effectiveness of antihypertensive medication for primary prevention of cardiovascular disease: systematic review and multiple treatments meta-analysis. BMC Med. 2012;10:33. https://doi.org/10.1186/1741-7015-10-33

14. Remonti LR, Dias S, Leitão CB, et al. Classes of antihypertensive agents and mortality in hypertensive patients with type 2 diabetesNetwork meta-analysis of randomized trials. J Diabetes Complications. 2016;30(6):1192-1200. https://doi.org/10.1016/j.jdiacomp. 2016.04.020

15. Qi H, Liu Z, Cao H, et al. Comparative Efficacy of Antihypertensive Agents in Salt-Sensitive Hypertensive Patients: A Network Meta-Analysis. Am J Hypertens. 2018;31(7):835-846. https://doi.org/10.1093/ajh/ hpy027

16. Wright JM, Musini VM, Gill R. First-line drugs for hypertension Cochrane Database Syst Rev. 2018;4:CD001841. https://doi.org/10. 1002/14651858.CD001841.pub3 
17. MEPS HC-201 2017 full year consolidated data file. August 2019. https://meps.ahrq.gov/data_stats/download_data/pufs/h201/ h201doc.pdf. Accessed February 7, 2020.

18. Cohen J. Design and Methods of the Medical Expenditure Panel Survey Household Component. MEPS Methodology Report No 1.; 1997. https:// meps.ahrq.gov/data_files/publications/mrl/mrl.shtml. Accessed February 7,2020 .

19. Cohen JW, Monheit AC, Beauregard KM, et al. The Medical Expenditure Panel Survey: a national health information resource. Inquiry. 1996;33(4):373-389.

20. Cohen JW, Cohen SB, Banthin JS. The medical expenditure panel survey: a national information resource to support healthcare cost research and inform policy and practice. Med Care. 2009;47(7 Suppl 1):S44-50. https://doi.org/10.1097/MLR.0b013e3181a23e3a

21. Hill SC, Zuvekas SH, Zodet MW. Implications of the accuracy of MEPS prescription drug data for health services research. Inquiry. 2011;48(3):242-259. https://doi.org/10.5034/inquiryjrnl_48.03.04

22. Carter BL, Ernst ME, Cohen JD. Hydrochlorothiazide versus chlorthalidone: evidence supporting their interchangeability. Hypertens. 2004;43(1):4-9. https://doi.org/10.1161/01.HYP. 0000103632.19915.0E

23. Olde Engberink RHG, Frenkel WJ, van den Bogaard B, Brewster LM, Vogt $\mathbf{L}$, van den Born B-JH. Effects of thiazide-type and thiazide-like diuretics on cardiovascular events and mortality: systematic review and meta-analysis. Hypertens. 2015;65(5):1033-1040. https://doi.org/10. 1161/HYPERTENSIONAHA. 114.05122

24. Roush GC, Ernst ME, Kostis JB, Tandon S, Sica DA. Head-to-head comparisons of hydrochlorothiazide with indapamide and chlorthalidone: antihypertensive and metabolic effects. Hypertens. 2015;65(5):10411046. https://doi.org/10.1161/HYPERTENSIONAHA. 114.05021

25. Lederle FA, Cushman WC, Ferguson RE, Brophy MT, Fiore Md LD. Chlorthalidone Versus Hydrochlorothiazide: A New Kind of Veterans Affairs Cooperative Study. Ann Intern Med. 2016;165(9):663-664. https://doi.org/10.7326/M16-1208

26. Abraham B, Megaly $\mathbf{M}$, Sous $\mathbf{M}$, et al. Meta-Analysis Comparing Torsemide Versus Furosemide in Patients With Heart Failure. Am J Cardiol. 2020;125(1):92-99. https://doi.org/10.1016/j.amjcard. 2019.09.039

27. Ram CVS. Beta-blockers in hypertension. Am J Cardiol. 2010;106(12):1819-1825. https://doi.org/10.1016/j.amjcard.2010. 08.023

28. Parker ED, Margolis KL, Trower NK, et al. Comparative effectiveness of 2 $\beta$-blockers in hypertensive patients. Arch Intern Med. 2012;172(18):1406-1412. https://doi.org/10.1001/archinternmed. 2012.4276

29. Carlberg B, Samuelsson O, Lindholm LH. Atenolol in hypertension: is it a wise choice? Lancet. 2004;364(9446):1684-1689. https://doi.org/10. 1016/S0140-6736(04)17355-8

30. SPRINT Research Group, Wright JT, Williamson JD, et al. A Randomized Trial of Intensive versus Standard Blood-Pressure Control. N Engl J Med. 2015;373(22):2103-2116. https://doi.org/10.1056/ NEJMoa 1511939

31. James PA, Oparil S, Carter BL, et al. 2014 evidence-based guideline for the management of high blood pressure in adults: report from the panel members appointed to the Eighth Joint National Committee (JNC 8). JAMA. 2014;311(5):507-520. https://doi.org/10.1001/jama. 2013.284427

32. Saklayen MG, Deshpande NV. Timeline of History of Hypertension Treatment. Front Cardiovasc Med. 2016;3:3. https://doi.org/10.3389/ fcrm.2016.00003

33. Furberg CD, Psaty BM, Meyer JV. Nifedipine. Dose-related increase in mortality in patients with coronary heart disease. Circulation. 1995;92(5):1326-1331. https://doi.org/10.1161/01.cir.92.5.1326

34. Tedla YG, Bautista LE. Drug Side Effect Symptoms and Adherence to Antihypertensive Medication. Am J Hypertens. 2016;29(6):772-779. https://doi.org/10.1093/ajh/hpv 185

35. van der Laan DM, Elders PJM, Boons CCLM, Beckeringh JJ, Nijpels G, Hugtenburg JG. Factors associated with antihypertensive medication non-adherence: a systematic review. J Hum Hypertens. 2017;31(11):687694. https://doi.org/10.1038/jhh.2017.48

36. Dal-Ré $\mathbf{R}$, Janiaud P, Ioannidis JPA. Real-world evidence: How pragmatic are randomized controlled trials labeled as pragmatic? BMC Med. 2018;16(1):49. https://doi.org/10.1186/s12916-018-1038-2

37. Sahakian Y, Bylykbashi B, Rahman A. Prescribing Patterns of Antihypertensive Medications in US Ambulatory Care Settings. Pharmacy (Basel). 2019;7(2):64. Published 2019 Jun 14. https://doi.org/10. 3390/pharmacy7020064.

38. Milchak JL, Carter BL, James PA, Ardery G. Measuring adherence to practice guidelines for the management of hypertension: an evaluation of the literature. Hypertension. 2004;44(5):602-608.

39. Gu A, Yue Y, Argulian E. Age Differences in Treatment and Control of Hypertension in US Physician Offices, 2003-2010: A Serial Crosssectional Study. Am J Med. 2016;129(1):50-58. e4.

40. Ardery G, Carter BL, Milchak JL, et al. Explicit and implicit evaluation of physician adherence to hypertension guidelines. J Clin Hypertens (Greenwich). 2007;9(2):113-119.

41. Messerli FH, Bangalore S, Bavishi C, Rimoldi SF. AngiotensinConverting Enzyme Inhibitors in Hypertension: To Use or Not to Use?. J Am Coll Cardiol. 2018;71(13):1474-1482.

42. Wilkes MS, Bell RA, Kravitz RL. Direct-to-consumer prescription drug advertising: trends, impact, and implications. Health Aff Proj Hope. 2000; 19(2): 110-128. https://doi.org/10.1377/hlthaff.19.2.110

43. Carey C, Lieber E, Miller S. Drug Firms' Payments and Physicians' Prescribing Behavior in Medicare Part D. Natl Bur Econ Res Work Pap. February 2020: 1-52.

44. Fleischman W, Ross JS, Melnick ER, Newman DH, Venkatesh AK. Financial Ties Between Emergency Physicians and Industry: Insights From Open Payments Data. Ann Emerg Med. 2016;68(2):153-158. e4. https://doi.org/10.1016/j.annemergmed.2016.01.014

45. Vijay A, Gupta R, Liu P, Dhruva SS, Shah ND, Ross JS. Medicare Formulary Coverage of Brand-Name Drugs and Therapeutically Interchangeable Generics. J Gen Intern Med. 2019. https://doi.org/10.1007/ s11606-019-05432-6

Publisher's Note: Springer Nature remains neutral with regard to jurisdictional claims in published maps and institutional affiliations. 